\title{
WHAT IS THE BEST WAY TO ANALYZE PRE-POST DATA?
}

Adib Rifqi Setiawan

MI NU Tasywiquth Thullab Salafiyyah (TBS) Kudus

Jl. KH. Turaichan Adjhuri, No. 234, Langgardalem, Kabupaten Kudus, 59315, Indonesia

adibrifqisetiawan@gmail.com

\begin{abstract}
Using pre- and posttest scores from two sections of natural science learning on theme 6 and 7 offered during January-February 2020 at 5th-A grade of MI NU Tasywiquth Thullab Salafiyyah (TBS) Kudus, we estimate how the commonly methods used in the PER, DBER, nor STEM-based education research literature i.e. comparing 1) raw change scores; 2) normalized gain scores; 3) normalized change scores; and 4) effect sizes; can lead to erroneous conclusions, and not an effective framework for distinguishing the impact of an instructional intervention from the impact of student characteristics on test score gains. It reveals the fundamental problem of four methods to analyze pre-post data.
\end{abstract}

Keywords: Research Methods; Statistical Analysis; Test Score Gains;

\section{INTRODUCTION}

The word "test" is being used throughout this work to indicate a tool or technique to assess behavior but should not be used synonymously with the term "dependent variable." The purpose of a test in the most general terms is to measure the nature and the extent of individual differences. For example, we might want to assess society' knowledge of how COVID-19 is transmitted (Ilmiyah, 2020), or see the effect of family planning allocation on village funding in increasing the use of Local Assistance Procedures Manual in some place (Ilmiyah, Damayanti, Nisa, Hartati, \& Dadun, 2018), or we may be interested in differences that exist on some measure of personality such as the Science Motivation Questionnaire II or an intelligence test such as Multiple Intelligences Survey (Setiawan, 2019). Tests also are instruments that distinguish among people on such measures as reaction time, physical strength, agility, or the strategy someone selects to solve a problem. Not all tests use paper and pencil the technique that a researcher uses to assess a behavior often reflects that researcher's creativity.

A good test should be able to differentiate people from one another reliably based on their true scores. Although we may use a test to assess some outcome, we may also use it for categorization or classification purposes. For example, if we want to investigate the effectiveness of two treatments in learning (inquiry or STEM based learning, for example) on obsessive-compulsive disorders, we would first use the results of a test to categorize subjects into severe or mild categories and then use another assessment to evaluate the effectiveness of each treatment nor improvement of student's learning score.

For the past several decades, researchers in physics education research (PER), disciplinebased education research (DBER), nor STEM-based education research have focused on testing whether educational interventions in classrooms lead to improved student understanding and performance. Most interventions are given at the classroom level, meaning that all students in a given classroom receive the intervention. For example, all students in a class may be exposed to a scientific approach learning (Nurohmah, 2015) or asked to participate in a STEM education based learning (Suwarma, 2014). 
To evaluate the impact of educational interventions like these on student performance, researchers typically collect student test scores before and after the intervention-that is, from a pretest and a posttest. Most researchers are interested in demonstrating that student test scores improve more in treatment classrooms than in control classrooms - that is, in sections that do receive the intervention versus sections that do not (Dinata, 2014), although some of them are interested in whether student scores improve after instruction (Amroni, 2013).

What is the best way to analyze pre-post data in this setting? At least four different methods for determining whether learning gains differ in the treatment and control classrooms are commonly used in the PER, DBER, nor STEM-based education research literature, i.e. comparing 1) raw change scores (Udovic, Morris, Dickman, Postlethwait, \& Wetherwax, 2002); 2) normalized gain scores (Setiawan, 2017; Hake, 1998); 3) normalized change scores (Sriyansyah \& Azhari, 2017; Marx \& Cummings, 2007); and 4) effect sizes (Nurohmah, 2015; Cohen, 2013). In this work, we use test score data from two sections of learnings to illustrate how each of the four commonly used methods can lead to misleading conclusions.

\section{LITERATURE REVIEW}

\section{Raw Change Scores}

Udovic et al. (2002) compare student learning gains in a "workshop" introductory biology course, which included numerous active-learning activities, with learning gains in comparison courses taught primarily through lectures. They use a $t$ test to compare what we refer to as "raw change scores" between treatment and control classes. Raw change scores are simply the difference between the postscore and the prescore, that can expressed as:

$$
\text { raw score }=\text { post }- \text { pre }
$$

where pre- and postscores are expressed as the average percent correct in each class in the study. Udovic and coworkers contend that if student scores in the treatment course improve more, on average, from the pretest to the posttest than do student scores in the control course, then the gains must be due to the intervention in the treatment courses. This procedure is identical-meaning that it will result in the same $p$-value and conclusions regarding the effect of the intervention- to the two-way repeated-measures analysis of variance (ANOVA) used by Martin et al. (2007).

In both the treatment and control classes, the authors compute the average raw change for each of the 11 questions on their pre- and posttest. The mean raw change was higher in the treatment classes than in the control classes for all 11 questions, and the $t$ test rejected the null hypothesis that the mean raw change scores were equal for seven of the 11 questions. The authors conclude that the active-learning strategies in the treatment courses had a significant impact on student learning gains.

Analyzing raw change is attractive in terms of simplicity but does not account for the observation that students with low scores on a pretest have more to gain than students who score higher. The problem arises because test scores are bounded-meaning that they have an upper limit. To account for differences in "ease of improving" from pre to post, researchers have used two methods for standardizing or normalizing gain scores, one at the classroom level and one at the student level. 


\section{Normalized Gain Scores}

Normalized gain scores is the method that I used in my undergraduate thesis (Setiawan, 2017). In fact, it is the first method that I know how to use it, although my friend Eva Fauziah Nurohmah showed effect sizes that used in her undergraduate thesis (Nurohmah, 2015). So, normalized gain scores seem as my common method when I evaluate the impact of educational interventions, e.g. when I used scientific approach in biology learning at MA NU Tasywiquth Thullab Salafiyyah (TBS) Kudus (Setiawan, 2019).

Normalized gain scores introduces by Hake (1998) when compares student learning gains on the Force Concept Inventory across 62 different introductory physics courses. In 48 of these courses, instructors had made substantial use of interactive-engagement methods. Hake considers these the treatment classes, while the 14 courses that were based on traditional lecturing are the control classes. For each class, Hake calculates the "average normalized gain," symbolized $\langle g\rangle$, as the ratio of the average gain from pretest to posttest to the maximum possible gain, using the following formula:

$$
\langle g\rangle=\frac{(\text { post }- \text { pre })}{(100-\text { pre })}
$$

He reports that the average normalized gain in the treatment courses was $0.48 \pm 0.14 S D$, while the average normalized gain in the control courses was $0.23 \pm 0.04 S D$. Although he did not perform a formal statistical hypothesis test, he concludes that interactive-engagement methods have a significant positive impact on student learning gains. Had he performed a $t$ test of the average normalized gains, the $p$-value would have been $<0.001$-more than enough evidence to make the same conclusion.

I used the normalized learning gain $\langle g\rangle$, in my undergraduate thesis for several reason-these are, maybe, lead the normalized learning gain became popular in the PER literature. First, the size of Hake's initial study made it possible for researchers to compare learning gains informally across classrooms, even if their own study did not include enough classes to make a formal statistical test possible. That is, researchers could compute $\langle g\rangle$ for one or a few classrooms under study and make a judgment about whether the values are similar to those reported in the Hake study, my undergraduate thesis is an example. Second, by normalizing by the maximum gain possible in each class, it accounts for the fact that some classrooms have more room to gain than other classrooms. A class that scores an $80 \%$ on the pretest and a $90 \%$ on the posttest has an average normalized gain of 0.5 , matching a class that scores $60 \%$ on the pretest and $80 \%$ on the posttest (i.e., each class gained exactly half of the amount it could have gained on the posttest). Finally, in studies with large numbers of treatment and control classrooms, $\langle g\rangle$ can be used to formally test whether learning gains in the treatment classes are larger than in the control classes. However, using $\langle g\rangle$ results in low sample sizes and thus poor statistical power, because it uses the class as the unit of analysis instead of using individual students - in fact, this case currently happening in my thematic learning's classroom.

\section{Normalized Change Scores}

As an alternative to Hake's normalized gain measure, Marx and Cummings (2007) constructed a student-level called the normalized change score, symbolized $c$. Instead of computing learning gains at the classroom level with $\langle g\rangle$, they advocate calculating learning gains at the student level, using the following formula: 


$$
c=\left\{\begin{array}{c}
\frac{(\text { post }- \text { pre })}{(100-\text { pre })} \text {; if post }>\text { pre } \\
\text { drop } ; \text { if post }=\text { pre }=100 \text { or } 0 \\
0 ; \text { if } 0<\text { post }=\text { pre }<100 \\
\frac{(\text { post }- \text { pre })}{\text { post }} ; \text { if post }<\text { pre }
\end{array}\right.
$$

For students who score higher on the posttest than the pretest, the student-level normalized change score is computed similarly to a classroom-level normalized gain. The last three possibilities deal with unusual circumstances: students who score 0 or 100 on both the preand posttest are dropped; students who score the same on the pre- and posttest get a 0 ; and students who score lower on the posttest than the pretest have this negative gain scaled by the possible number of points they could have lost.

Because normalized change scores compare learning gains for students rather than for classrooms, they have two substantial advantages over normalized gain scores. First, they can be used to compare the impact of interventions assigned within classrooms rather than across classrooms, e.g. Sriyansyah \& Azhari (2017) for an example. Second, because the observations are at the student level rather than at the classroom level, the sample size is substantially larger compared with using normalized change scores, providing increased statistical power. Normalized change scores have an important limitation, however. If students get a perfect score on the posttest, their $c$ is 1 no matter whether their prescore was $1 \%$ or $99 \%$. Similarly, if students score the same on the pre- and posttest, their score is 0 , no matter whether their prescore was $1 \%$ or $99 \%$. In these cases, the goal of normalizing for "ease of improvement" is lost.

\section{Effect Sizes}

Nurohmah (2015) collect pre- and posttest score on the multiple choice questions and physics motivation questionnaire (PMQ) from a sample of scientific approach learning classroom consisting of 32 students, and compare learning gains from an experimental class without involving the control one. To quantify learning gains at the classroom level, she use a metric known as an effect size. Effect sizes are commonly used in meta-analyses because they put estimated treatment effects from different studies in a common scale (Cohen, 2013). For example, researchers can calculate a standardized mean difference, which expresses the difference between groups in units of SD, using Cohen's $d$ statistic or a variant called Hedges' $g$. With pre-post data from identical assessments, it is appropriate to use a modification of Cohen's $d$ that accounts for the same students being tested twice. Thus, she calculate the effect size for her class using the following formula:

$$
d=\frac{\left(\bar{X}_{\text {post }}-\bar{X}_{\text {pre }}\right)}{\left(\frac{S_{g}}{\sqrt{2(1-r)}}\right)}
$$

where $\bar{X}_{\text {post }}$ and $\bar{X}_{\text {pre }}$ are the average scores on the post- and pretest, $S_{g}$ is the SD of the raw gain scores, and $r$ is the correlation between student scores on the pre- and posttests. Nurohmah estimate a classroom-level linear regression using each class's effect size as the dependent variable, and find that the scientific approach has a high effectiveness in improving the students' result, although based on PMQ scientific approach has lower effectiveness in improving every motivational component aspect. 
Effect size is commonly used in DBER literature, but not PER and STEM based education researchers (Nissen, Talbot, Thompson, \& Dusen, 2018). So, Nurohmah' use of linear regression is an important addition to the PER education literature, as it allows them to control for factors other than active learning - such as the teacher's position and years of teaching experience, class size, and student-rated course difficulty-that could influence learning gains in the treatment and control classrooms. However, Nurohmah estimate her result at the classroom level and do not have access to student characteristics that can be used as control variables.

A large education research literature demonstrates that observable student characteristics are often correlated not just with student performance but also with student learning gains (Goldhaber, Krieg, \& Theobald, 2020; Shores \& Steinberg, 2017; Krzywacki, Kim, \& Lavonen, 2016). Thus, this approach-like the prior three methods we reviewed-does not account for the possibility that differences in student learning gains, or lack thereof, are due to differences in the characteristics of students in the treatment and control classrooms rather than to the effect of the intervention.

\section{METHOD}

To illustrate the importance of controlling for observable student characteristics in the treatment and control classes when evaluating the impact of nonrandomized educational interventions, we apply the four methods above to pre- and posttest scores from two sections of natural science learning on theme 6 and 7 offered during January-February 2020 at 5th-A grade of MI NU Tasywiquth Thullab Salafiyyah (TBS) Kudus.

Fortunately, besides that it was taught by the same teacher (i.e. author), each section using the exact same materials (i.e. heat) and instructional strategies (i.e. scientific approach). Thus, assuming without knowing anything about the student composition of the "two classes", there is no a priori reason to expect different student performance in the "two classes".

Given that there is actually no treatment at all — just because scientific approach is commonly model used in the "two classes", this should be an example of a statistical test wherein the null hypothesis - that the treatment had no impact on student learning gains-should not be rejected. We will label one of these sections as the treatment (section BL $\Lambda$ OK for Theme 6) and the other section as the control (section PIИK form Theme 7).

We will demonstrate that each of the methods above does lead to the conclusion that, for this particular pair of sections in this particular learning, score gains in the treatment class (section BL $\Lambda \mathrm{DK}$ ) are higher than in the control class (section PIИK). This would ordinarily be taken as evidence that the "instructional intervention" in the treatment class had a significant impact on student learning gains. But given that there was no intervention at all, we explore whether the student composition of these two particular sections may have contributed to the incorrect conclusion.

Throughout the analysis that follows, we interpret the results of all tests of statistical significance at the $95 \%$ confidence level-meaning that the $p$ value must be $<0.05$ to reject the null hypothesis. We caution, however, against overreliance on conventional levels of statistical significance. 


\section{RESULTS}

\section{Data Overview}

At the start of the term, students in each section took a concept test, converted to a 100-point scale, that was intended to measure their prior knowledge about the topics to be covered in the learning. Then 3 weaks into the learning, students took an in-class exam on the same material-also graded on a 100-point scale - that covered material taught in the first 3 weeks of the learning. We will treat a concept test as the pretest and the in-class exam as the posttest. The average pretest scores were 68.343 ( $\mathrm{SD}=15.507)$ in section BL $\Lambda$ DK (the "treatment" section) and 68.429 (SD = 8.896) in section PIИK (the "control" section), and are not significantly different between the two sections (the $t$ stat $=-3,306<t$ critical $=1,668$ ). This is important because common assumptionis the treatment and control classes have similar incoming characteristics if the pretest scores are not significantly different. The average posttest scores were $79.343(\mathrm{SD}=17.263)$ in the BL $\Lambda$ DK section and $79.314(\mathrm{SD}=$ 17.327 ) in the PIИK section, which a $t$ test indicates is significantly different ( $p$-value $=$ $0,003282304<$ alpha $\alpha=0.050$ ). We now analyze these data using the four methods discussed in the preceding section.

\section{Raw Change Scores}

In the BL $\Lambda \mathrm{OK}$ class, the average raw change score is $79.343-68.343=11.000(S D=$ 15.8), while in the PIИK class, the average raw change score is $79.314-68.429=$ $10.886(S D=15.0)$. A $t$ test of the null hypothesis that these average raw change scores are the same gives a $p$ value of 0.487 , which is statistically significant at the $95 \%$ confidence level $(\alpha=0.05)$. Thus, with this methodology, there is sufficient evidence to accept the null hypothesis and conclude that student learning gains were no difference in the treatment and control class.

\section{Normalized Gain Scores}

The normalized gain score in the BL $\Lambda \mathrm{OK}$ class is $\frac{(79.343-68.343)}{(100-68.343)}=0.347(S D=0.496)$, while the normalized gain in the PIИK class is $\frac{(79.314-68.429)}{(100-68.429)}=0.345(S D=0.519)$. Because we are limited to only one treatment class and one control class, there is no way to statistically test whether these normalized gain scores are significantly different. That said, the magnitude of the difference may lead to the conclusion that student learning gains were greater in the treatment class than in the control class.

\section{Normalized Change Scores}

The average normalized change score in the BL $\Lambda \mathrm{DK}$ class is $0.420(S D=0.418)$, while the average normalized change score in the PIИK class is $0.391(S D=0.465)$. A $t$ test of the null hypothesis that these average normalized changes scores are the same gives a $p$-value of 0.394, which is statistically significant. Thus, with this methodology, there is sufficient evidence to accept the null hypothesis, but the difference of normalized change score can conclude that student learning gains in the treatment class better than control class. 


\section{Effect Sizes}

The correlation between student scores on the pre- and posttests for the BL $\Lambda$ DK class is $r=0.441$. Thus, the effect size for the BL $\Lambda \mathrm{DK}$ class is 0.790 . In other data, the correlation between student scores on the pre- and posttests for the PIИK class is $r=0.613$, so the effect size is 0.670 . As with normalized gains, there is no way to test whether these effect sizes are significantly different with only one BL $\Lambda$ DK and one PIИK class. That said, the magnitude of the difference between the two classes may lead to the conclusion that learning gains in the treatment class were larger than learning gains in the control class.

\section{DISCUSSION}

Table 1. Summary comparison of estimated results

\begin{tabular}{cccc}
\hline Method & $\begin{array}{c}\text { BLADK } \\
\text { (treatment } \\
\text { class) }\end{array}$ & $\begin{array}{c}\text { PIVK } \\
\text { (control } \\
\text { class) }\end{array}$ & Conclusion \\
\hline $\begin{array}{c}\text { Raw Change } \\
\text { Scores }\end{array}$ & 11.000 & 10.886 & $\begin{array}{c}\text { Student learning gains were no difference in the } \\
\text { treatment and control class. }\end{array}$ \\
\hline $\begin{array}{c}\text { Normalized } \\
\text { Gain Scores }\end{array}$ & 0.347 & 0.345 & $\begin{array}{c}\text { Student learning gains were greater in the treatment } \\
\text { class than in the control class. }\end{array}$ \\
\hline $\begin{array}{c}\text { Normalized } \\
\text { Change Scores }\end{array}$ & 0.347 & 0.345 & $\begin{array}{c}\text { A } t \text { test conclude that there was no difference in the } \\
\text { treatment and control class, but the difference of } \\
\text { normalized change score can conclude that student } \\
\text { learning gains in the treatment class better than } \\
\text { control class. }\end{array}$ \\
\hline Effect Sizes & 0.790 & 0.670 & $\begin{array}{c}\text { Learning gains in the treatment class were larger than } \\
\text { learning gains in the control class. }\end{array}$ \\
\hline
\end{tabular}

Two (or may three) of the above methods, i.e. normalized gain scores and effect sizes (and normalized change score without $t$ test), could lead to the conclusion that the intervention in the treatment class had a positive impact on student learning gains. But given that there was no intervention at all, there must be another explanation for the observed difference in learning gains. One possibility is that the differences occurred by chance. The $p$-value for a $t$ test comparing normalized change scores tells us that there is a $39.416 \%$ chance of observing differences this extreme by chance alone, while raw change scores is $48.738 \%$. Another more probable explanation, though, is that the student composition of the two sections is driving the differences.

This estimation underlines the central message of this work. The gold standard for evaluating the impact of treatments of any kind - educational or otherwise - is a large randomized controlled trial. If sample sizes are large and if treatments are randomly assigned to the experimental subjects (or students, in this case), then there is no reason to expect the treatment and control groups to differ in any way, except that the treatment group received the treatment, while the control group did not. But in the context of evaluating the impact of interventions in the classrooms, it is often not feasible to randomly assign students to treatment and control classes. The nonrandomized design that results opens up the possibility that the treatment and control classes will be substantially different, as our example shows. If these differences are correlated with student learning gains, then any of the methods above runs the risk of attributing observed differences to the impact of the treatment, when in reality they are due to differences in the composition of the groups being compared. This is true even if the treatment had no effect at all. 
We have shown that existing methods of evaluating interventions in classrooms can lead to erroneous conclusions when the interventions are not randomly assigned to students. We reveal that none of each of the four methods commonly used to assess educational interventions in the PER, DBER, nor STEM-based education research methods accounts for a fundamental problem: controlling for student equivalence, or lack thereof, in the classrooms being compared. The problem of student nonequivalence is pervasive, because it is seldom possible to use randomization to control for differences in student ability or preparation. Based on this fundamental problem, these tow of four methods would support the conclusion that an "instructional intervention" in the higher-performing section led to larger student learning gains, when in fact there was no intervention at all.

\section{CONCLUSION}

There was, at least, four different methods for determining whether learning gains differ in the treatment and control classrooms are commonly used in the PER, DBER, nor STEMbased education research literature: comparing 1) raw change scores; 2) normalized gain scores; 3) normalized change scores; and 4) effect sizes. Unfortunately, none of these methods accounts for a fundamental problem: controlling for student equivalence, or lack thereof, in the classrooms being compared.

The PER, DBER, nor STEM-based education research literature has made remarkable strides in recent years, but the methods commonly used to estimate the impact of instructional interventions lead to troubling questions about whether these treatment effects really are due to the interventions. It is intuitive to think of a student's performance on a test as a function of many factors as it explained by Siayah et al. (2020): the student's prior knowledge about the specific topics on the test, the student's motivation of the larger discipline, the student's learning habits and study skills, and the intervention itself. Given that many interventions in classroom cannot be randomized, is there a way to distinguish the impact of incoming student characteristics from the impact of the intervention itself?

\section{ACKNOWLEDGMENT}

This work is dedicated to my great academic's advisor Surotul Ilmiyah, of her amazing inspiring, motivating, and guiding my research, nor for her endless shaping my mindset and developing my skill.

\section{REFERENCES}

Amroni, Y. (2013). Enhancing the English Interaction of Second Semester Students of Muria Kudus University in Academic Year 2012/2013 outside the Classroom through Social Media Fanpage "SSF". Kudus: Universitas Muria Kudus (UMK).

Cohen, J. (2013). Statistical Power Analysis for the Behavioral Sciences (2ne Edition ed.). London: Routledge.

Dinata, A. N. (2014). Pengaruh Field Trip Terhadap Kemampuan Literasi Sains dan Sikap Sains Siswa SMA Pada Materi Ekosistem. Bandung: Universitas Pendidikan Indonesia.

Goldhaber, D., Krieg, J. M., \& Theobald, R. (2020, February 13). Exploring the Impact of Student Teaching Apprenticeships on Student Achievement and Mentor Teachers. Journal of Research on Educational Effectiveness . 
Hake, R. R. (1998). Interactive-engagement versus traditional methods: A six-thousandstudent survey of mechanics test data for introductory physics courses. American Journal of Physics , 66 (1), 64-74.

Ilmiyah, S. (2020, February 11). Surotul Ilmiyah - PBNU Menjawab Tantangan Virus Corona. Alobatnic.

Ilmiyah, S., Damayanti, R., Nisa, H., Hartati, H., \& Dadun. (2018). Village Funding Allocation for Improving the Use of Long-Acting and Permanent Methods of Contraception (LAPM) in West Nusa Tenggara Province. The 3rd International Meeting of Public Health and the 1st Young Scholar Symposium on Public Health (pp. 402-410). Dubai: KnE Life Sciences .

Krzywacki, H., Kim, B.-c., \& Lavonen, J. (2016). Physics Teacher Knowledge Aimed in Pedagogical Studies in Finland and in South Korea. EURASIA Journal of Mathematics, Science and Technology Education, 13 (1), 201-222.

Martin, T., Rivale, S. D., \& Diller, K. R. (2007). Comparison of Student Learning in Challenge-based and Traditional Instruction in Biomedical Engineering. Annals of Biomedical Engineering , 35, 1312-1323.

Marx, J. D., \& Cummings, K. (2007). Normalized change. American Journal of Physics , 75 (87), 87-91.

Nissen, J. M., Talbot, R. M., Thompson, A. N., \& Dusen, B. V. (2018). Comparison of normalized gain and Cohen's d for analyzing gains on concept inventories. Physical Review Physics Education Research, 14, 010115.

Nurohmah, E. F. (2015). Efektivitas Pendekatan Saintifik dalam Meningkatkan Hasil dan Motivasi Belajar Siswa SMP. Bandung: Universitas Pendidikan Indonesia (UPI).

Setiawan, A. R. (2019). Literasi Saintifik Berdasarkan Kecerdasan Majemuk dan Motivasi Belajar. Media Penelitian Pendidikan: Jurnal Penelitian dalam Bidang Pendidikan dan Pengajaran, 13 (2), 126-137.

Setiawan, A. R. (2017). Penerapan Pendekatan Saintifik untuk Melatihkan Literasi Saintifik dalam Domain Kompetensi pada Topik Gerak Lurus di Sekolah Menengah Pertama. Bandung: Universitas Pendidikan Indonesia.

Setiawan, A. R. (2019). Peningkatan Literasi Saintifik melalui Pembelajaran Biologi Menggunakan Pendekatan Saintifik. Journal of Biology Education , 2 (1), 223235.

Shores, K., \& Steinberg, M. P. (2017). The Impact of the Great Recession on Student Achievement: Evidence from Population Data. Amsterdam: Social Science Research Network.

Siayah, S., Kurniawati, N. K., \& Setiawan, A. R. (2020, February 29). Six Main Principles for Quality Learning based on "Ta'līm al-Muta'allim Torīq al-Ta'allum". ResearchGate.net (preprint).

Sriyansyah, S. P., \& Azhari, D. (2017). Addressing an Undergraduate Research Issue about Normalized Change for Critical Thinking Test. Jurnal Pendidikan IPA Indonesia , $6(1), 138-144$.

Suwarma, I. R. (2014). Research on Theory and Practice STEM Education Implementation in Japan and Indonesia using Multiple Intelligences Approach. Shizuoka: Shizuoka University.

Udovic, D., Morris, D., Dickman, A., Postlethwait, J., \& Wetherwax, P. (2002). Workshop Biology: Demonstrating the Effectiveness of Active Learning in an Introductory Biology Course. BioScience, 52 (3), 272-281. 
Appendix A. Data from two sections

Theme 6

Theme 7

\begin{tabular}{|c|c|c|c|c|c|}
\hline \multirow{3}{*}{ Number } & \multirow{3}{*}{ Student } & \multirow{2}{*}{\multicolumn{2}{|c|}{$\begin{array}{c}\text { (section BL } \Lambda \supset K \text { as treatment class) } \\
\text { Score }\end{array}$}} & \multirow{2}{*}{\multicolumn{2}{|c|}{$\begin{array}{c}\text { (section PIИK as control class) } \\
\text { Score }\end{array}$}} \\
\hline & & & & & \\
\hline & & Pretest & Posttest & Pretest & Posttest \\
\hline 1 & AZAR & 67 & 85 & 72 & 75 \\
\hline 2 & AZA & 69 & 71 & 63 & 81 \\
\hline 3 & $\mathrm{AAF}$ & 49 & 75 & 63 & 60 \\
\hline 4 & $\mathrm{AEH}$ & 57 & 84 & 62 & 71 \\
\hline 5 & $\mathrm{AF}$ & 66 & 88 & 62 & 100 \\
\hline 6 & $\mathrm{AHC}$ & 66 & 87 & 62 & 96 \\
\hline 7 & AJ & 96 & 100 & 75 & 100 \\
\hline 8 & ANK & 54 & 100 & 75 & 100 \\
\hline 9 & ARA & 84 & 76 & 79 & 88 \\
\hline 10 & $\mathrm{AZ}$ & 93 & 100 & 82 & 100 \\
\hline 11 & AZN & 90 & 100 & 76 & 100 \\
\hline 12 & AMN & 74 & 63 & 64 & 100 \\
\hline 13 & $\mathrm{AR}$ & 71 & 81 & 81 & 80 \\
\hline 14 & BAP & 68 & 80 & 84 & 88 \\
\hline 15 & BKJ & 77 & 100 & 62 & 88 \\
\hline 16 & $\mathrm{BP}$ & 67 & 100 & 66 & 91 \\
\hline 17 & EDP & 39 & 63 & 68 & 58 \\
\hline 18 & FIN & 49 & 44 & 69 & 58 \\
\hline 19 & MSH & 63 & 80 & 59 & 67 \\
\hline 20 & MAA & 73 & 97 & 63 & 84 \\
\hline 21 & MAH & 53 & 46 & 65 & 46 \\
\hline 22 & MCT & 76 & 74 & 78 & 79 \\
\hline 23 & MDS & 65 & 60 & 58 & 74 \\
\hline 24 & MFA & 40 & 71 & 59 & 67 \\
\hline 25 & MIB & 58 & 94 & 68 & 91 \\
\hline 26 & MKA & 56 & 65 & 54 & 38 \\
\hline 27 & MNA & 86 & 94 & 78 & 100 \\
\hline 28 & MNY & 94 & 91 & 82 & 100 \\
\hline 29 & MRA & 50 & 49 & 53 & 76 \\
\hline 30 & MTH & 57 & 55 & 53 & 65 \\
\hline 31 & MWA & 90 & 100 & 75 & 79 \\
\hline 32 & NMI & 53 & 55 & 75 & 48 \\
\hline 33 & SRS & 80 & 88 & 63 & 67 \\
\hline 34 & YSM & 80 & 91 & 69 & 73 \\
\hline 35 & $\mathrm{ZF}$ & 82 & 70 & 78 & 88 \\
\hline
\end{tabular}

